\title{
Bone sequestration after dental implant surgery
}

\author{
- Claudia Carrara Cotomacio School of Dentistry, Paulista University (Unip), São Paulo, SP, Brazil • Wladimir \\ Gushiken de Campos Department of Oral Medicine, School of Dentistry, University of São Paulo (USP), São Paulo, \\ SP, Brazil • Celso Augusto Lemos Department of Oral Medicine, School of Dentistry, University of São Paulo (USP), \\ São Paulo, SP, Brazil • Fabio Abreu Alves Stomatology Department, A.C.Camargo Cancer Center, São Paulo, SP, Brazil
}

ABSTRACT | Background. Dental implants are used to rehabilitate missing teeth, and despite high success rates, failures are inevitable. Ostensibly avoidable human errors in planning or technique can contribute to implant failure. Case presentation. Herein, we report a case of an unsuccessful dental implant surgery due to an inadequate surgical technique and bone exposure in a 54-year-old healthy woman. Conclusions. This report underscores the relevance of reporting the consequences of these human factors, such as loss of the implant, alveolar bone segment, and three teeth.

DESCRIPTORS | Case-report/series; Computerized Tomography; Oral and Maxillofacial; Oral Implant; Osteonecrosis.

RESUMO | Sequestro ósseo após cirurgia de implante dentário • Contexto. Os implantes dentários estão cada vez mais sendo usados para reabilitar a falta de dentes e, apesar das altas taxas de sucesso, falhas são inevitáveis. Erros humanos ostensivamente evitáveis no planejamento ou na técnica podem contribuir para a falha do implante. Apresentação do caso. Relatamos aqui um caso de cirurgia de implante dentário malsucedida devido a uma técnica cirúrgica inadequada e exposição óssea em uma mulher saudável de 54 anos de idade. Conclusões. Este estudo ressalta a relevância de relatar as consequências desses fatores humanos, como perda do implante, segmento ósseo alveolar e três dentes.

DESCRITORES | Relato de Caso; Tomografia Computadorizada; Cirurgia Maxilofacial; Implante Dentário; Osteonecrose.

CORRESPONDING AUTHOR | Wladimir Gushiken de Campos Faculdade de Odontologia, Universidade de São Paulo, São Paulo, SP, Brazil • Av. Prof. Lineu Prestes, 2227 São Paulo, SP, Brazi • 05508-000 E-mail: wgushiken@hotmail.com

- Received Apr. 3,2020 • Accepted May 7, 2020.

- Dol: http://dx.doi.org/10.11606/issn.2357-8041.clrd.2020.168469 


\section{INTRODUCTION}

Dental implants are used to rehabilitate missing teeth. ${ }^{1}$ Despite high implant success rates, failures are inevitable. Dental implant losses are usually associated with systemic complications that impair osseointegration and osteonecrosis (ON), such as diabetes, osteoporosis, ${ }^{2,3}$ periodontitis, ${ }^{2,3}$ harmful habits (smoking), ${ }^{3}$ radiotherapy, or medication use. ${ }^{3} \mathrm{ON}$ has been related to dental implant loss, which is relatively rare, except for cases involving osteoradionecrosis or medication-related osteonecrosis of the mandible. ${ }^{2}$

More preoperative assessments, including assessments of bone availability and systemic conditions may avoid some unsuccessful conditions. ${ }^{4}$ Ostensibly avoidable human errors in planning or technique can contribute to implant failure. Notably, Computerized tomography (CT) in the therapeutic planning process may reduce failures when obtaining alveolar bone dimension measurements. ${ }^{5}$ Thus, the aim of this study was to report a case of unsuccessful dental implant surgery due to an inadequate surgical technique in a healthy patient.

\section{CASE PRESENTATION}

A 54-year-old woman who had been a smoker for 30 years was referred to our clinic with pain in the right side of her mandible, which had persisted for a month. During the anamnesis, the patient reported having undergone implant surgery 4 months before, to replace her missing right lower lateral incisor. No relevant systemic conditions were observed. At clinical examination, a bone exposition on the lingual surface of the mandible measuring $1.5 \mathrm{~cm}$ across was observed (Fig. 1.1). Pus drainage was also detected. A CT exam showed extensive bone sequestration associated with a dental implant in the region of the right lower premolars (Fig. 1.2). After both clinical and radiographic exams, ON was hypothesized. The patient denied any systemic symptoms, use of antiresorptive drugs, and head or neck radiotherapy. Her blood cell count was normal. Therefore, our main diagnosis hypothesis was bone sequestration associated with implant surgery.

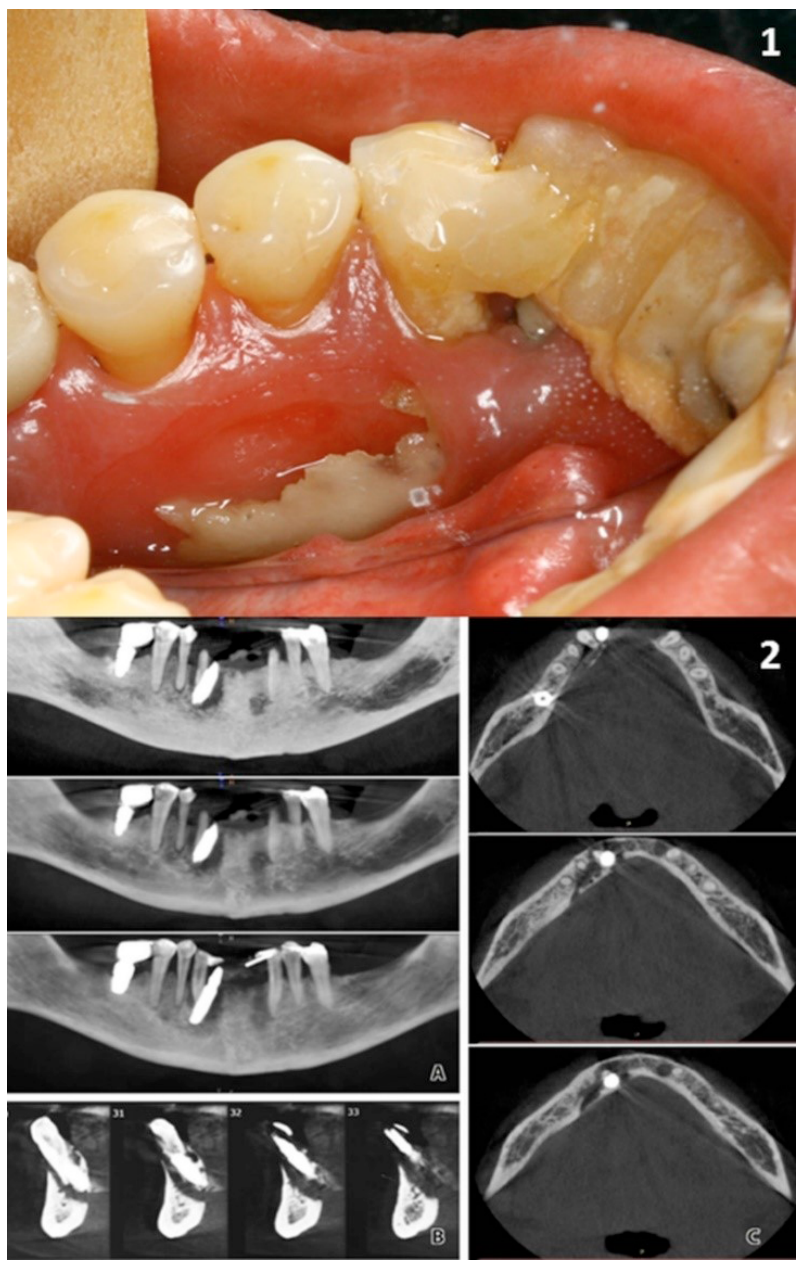

FIGURE 1 | 1.1. Bone sequestration at the lingual surface of the mandible. 1.2. Preoperative CT. A: Panoramic view; B: Sagittal slices; C: Axial slices.

The patient was treated with clindamycin (300 mg, 4 times a day for 10 days), underwent surgical removal of the sequestered bone, and extracted both right lower premolars and right lower canine tooth. In addition, alveolar ridge planning and suture were performed. Examination of the excised sequestered bone specimen revealed the presence of a firmly adhered implant (Fig. 2). Histopathology showed necrotic bone. During the 6-month follow-up period, the transitory paresthesia and the oral mucosa in the operated region healed 
completely (Fig. 3.1). A 6-month follow-up CT exam confirmed replenishment of healthy bone (Fig. 3.2).

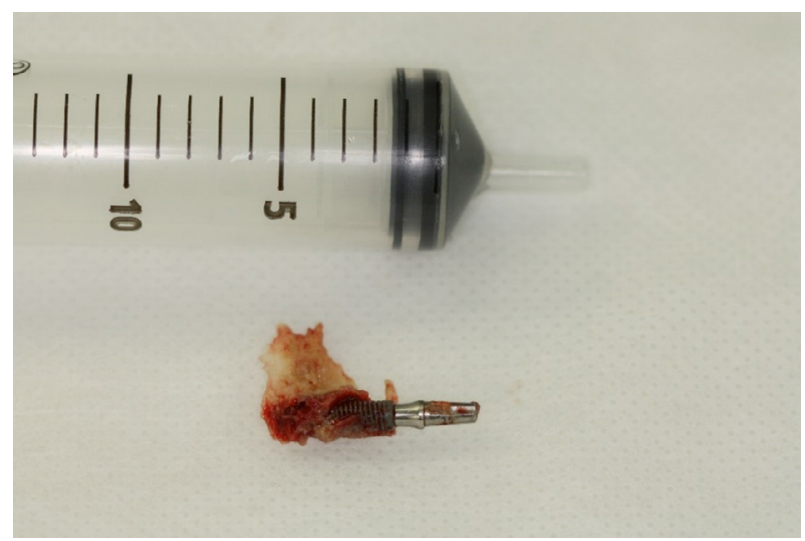

FIGURE 2 || Implant and bone sequestration.

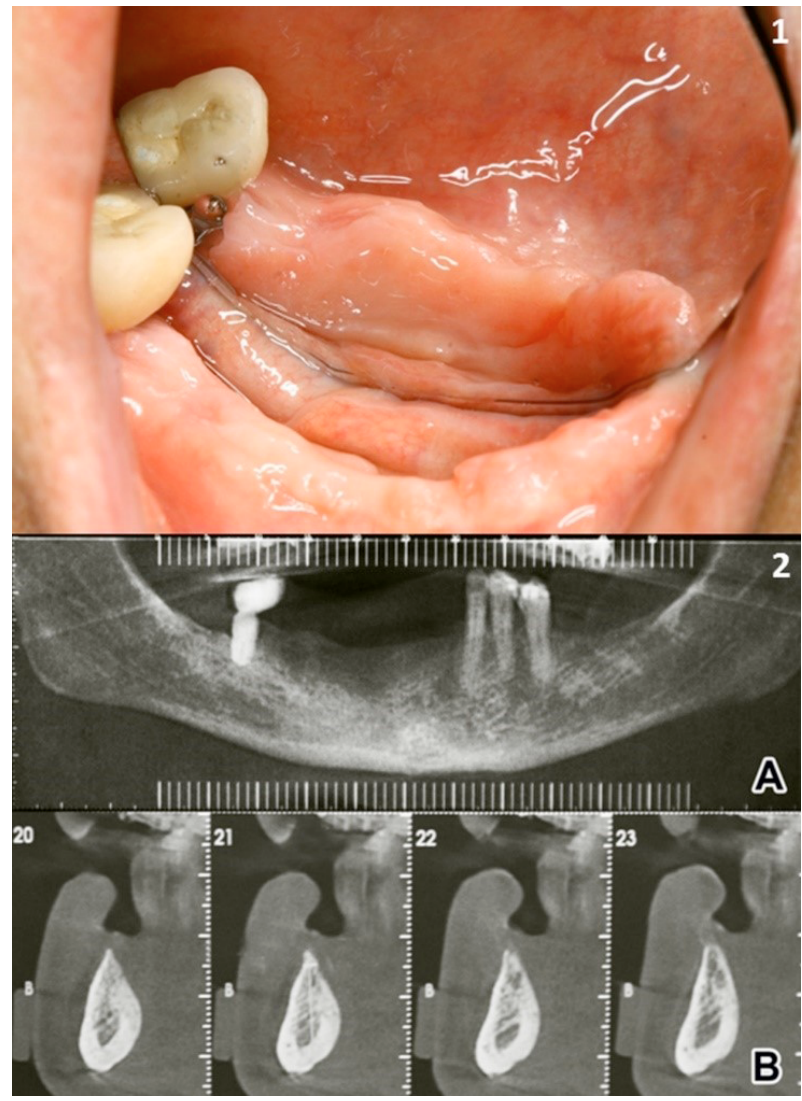

FIGURE 3 || 3.1. Surgery region, 6-month follow-up. 3.2. 6-month follow-up CT. A: Panoramic view; B: Sagittal slices.

\section{DISCUSSION}

The lack of typical causes of implant failure, such as a systemic disease or medications, led us to contemplate alternative causes. Despite the scientific evidence suggesting that smoking is associated with increased rates of implant failure and marginal bone loss, ${ }^{6,7}$ there was apparent osteointegration, evidenced by the implant being firmly attached to an excised bone fragment (Fig. 3). If the implant had been removed alone, osseointegration failure could have been suspected, which would make us assume that smoking was the major cause of failure in the absence of other systemic factors.

Clinical and radiographic signs suggested that lingualized implant placement triggered a fracture of the lingual cortical mandible due to an excessive load on the provisory prosthesis. If an implant causes expansion stress that exceeds the stress capacity of the local bone tissue, a fracture occurs. ${ }^{8}$ However, there is limited information about the relationship between implant loss and surgery techniques. Therefore, to estimate the influence inappropriate surgery planning or technique exerts on implant loss is not possible yet.

Even with unsatisfactory surgery planning, other factors can contribute to implant failure, such as the number of implants, implant location, and availability of bone.9,10 A higher number of implants improve masticatory force dissipation, avoiding overload. ${ }^{10}$ Relative to other regions, the anterior mandible has relatively thick and hard cortical bone with a lesser blood supply, ${ }^{9}$ an important factor that must be considered in vestibular-lingual implant placement. In this case, the implant was placed lingually and inclined to the right side. These placement factors favor bone sequestration.

\section{CONCLUSION}

In light of the lack of prior research, examination of implant loss due to inadequate surgical planning and techniques, this report underscores the relevance of reporting the consequences of these human factors, 
such as loss of the implant, alveolar bone segment, and three teeth.

\section{List of abbreviations used \\ ON: Osteonecrosis \\ CT: computerized tomography}

\section{Declarations:}

\section{Ethics approval and consent to participate}

Ethics committee: Not applicable. The patient agreed to participate in this case report

\section{Consent for publication}

Written informed consent form to publish this Case report and any accompanying images was obtained from the patient. A copy of the written consent is available for review by the Editor of this journal.

\section{Availability of data and material}

The datasets used and/or analyzed during this study can be obtained from the corresponding author on reasonable request.

\section{Competing interests}

The authors CCC, WGC, CAL and FAA declare no conflicts of interest

\section{Funding}

Not applicable.

\section{Authors' contributions}

Each author contributed to the study as follows: at the clinic, FA and $\mathrm{CC}$ were responsible for examining and diagnosing the patient, and WC and CL were responsible for the treatment and surgery. All authors read and approved the final manuscript.

\section{Acknowledgements}

Not applicable

\section{REFERENCES}

1. Gomes GH, Misawa MYO, Fernandes C, Pannuti CM, Saraiva L, Huynh-Ba G, et al. A systematic review and meta-analysis of the survival rate of implants placed in previously failed sites. Braz Oral Res. 2018;32:1-13. doi: 10.1590/1807-3107bor-2018.vol32.0027.

2. Schlund M, Raoul G, Ferri J, Nicot R. Mandibular osteomyelitis following implant placement. J Oral Maxillofac Surg. 2017;75(12):2560.e1-2560.e7. doi: https://doi.org/10.1016/ j.joms.2017.07.169.

3. Chen H, Liu N, Xu X, Qu X, Lu E. Smoking, radiotherapy, diabetes and osteoporosis as risk factors for dental implant failure: a meta-analysis. PLoS One. 2013;8(8):e71955. doi: https:/doi. org/10.1371/journal.pone.0071955.

4. Duyck J, Naert I. Failure of oral implants: aetiology, symptoms and influencing factors. Clin Oral Investig. 1998;2(3):102-14. doi: https://doi.org/10.1007/s007840050054.

5. Greenberg AM. Digital technologies for dental implant treatment planning and guided surgery. Oral Maxillofac Surg Clin North Am. 2015;27(2):319-40. doi: https://doi.org/10.1016/j.coms.2015.01.010.

6. Alfadda SA. Current evidence on dental implants outcomes in smokers and nonsmokers: a systematic review and meta-analysis. J Oral Implantol. 2018;44(5):390-9. doi: https://doi.org/10.1563/ aaid-joi-D-17-00313.

7. Veitz-Keenan A. Marginal bone loss and dental implant failure may be increased in smokers. Evid Based Dent. 2016;17(1):6-7. doi: https://doi.org/10.1038/sj.ebd.6401145.

8. dos Santos PL, Gaujac C, Shinohara EH, Filho OM, Garcia-Junior IR. Incomplete mandibular fracture after lateralization of the inferior alveolar nerve for implant placement. J Craniofac Surg. 2013;24(3): e222-4. doi: https://doi.org/10.1097/SCS.obo13e318286992e.

9. Lin G, Ye S, Liu F, He F. A retrospective study of 30,959 implants: risk factors associated with early and late implant loss. J Clin Periodontol. 2018;45(6):733-43. doi: https://doi.org/10.1111/jcpe.12898.

10. Kern JS, Kern T, Wolfart S, Heussen N. A systematic review and meta-analysis of removable and fixed implant-supported prostheses in edentulous jaws: post-loading implant loss. Clin Oral Implants Res. 2016;27(2):174-95. doi: https://doi.org/10.1111/clr.12531. 